\title{
AFTERWORD \\ PLACES, MIGRATION AND SUSTAINABILITY: ANTHROPOLOGICAL REFLECTIONS ON MINING AND MOVEMENT
}

Martha Macintyre

\begin{abstract}
Based on ethnographic research around the Misima and Lihir gold mines in Papua New Guinea this Afterword provides anthropological reflections on the main themes of the articles in this issue. Endorsing the call for interdisciplinary research on mining, I present instantiations of the varying meanings of place, migration and sustainability. I describe variations in perceptions of place between different sites and these are also subject to change over time. The commoditisation of land and engagement with capitalism profoundly alter knowledge and understanding of place and ideals of development. Migration occurs at different rates over the life of the mine but has a lasting effect on the stability of the community and its economic sustainability. Mining companies often resort to simplistic and inadequate solutions to the environmental and social problems created by their projects.
\end{abstract}

KEYWORDS: mining; Papua New Guinea; anthropology; migration; sustainability

This is the author manuscript accepted for publication and has undergone full peer review but has not been through the copyediting, typesetting, pagination and proofreading process, which may lead to differences between this version and the Version of Record. Please cite this article as doi: $10.1002 /$ sd.1895

This article is protected by copyright. All rights reserved. 
Mining generates movement, and as the contributors to this special issue demonstrate, the movements of people, resources, capital and profits have profound effects on stability and sustainability. There are collision courses and cooperative ventures. There is pillaging and destruction. The complexity of the flows and movements associated with mining, along with the imbrication of effects on communities and landscapes - people and places - makes analysis daunting. The framework proposed by Bebbington and Humphreys Bebbington (2018) offers theoretical scaffolding for building knowledge and developing interpretations of these processes. They draw on the disciplines of Geography and Development Studies while acknowledging the need for interdisciplinary collaboration that encompasses the complexities of mining and sustainability. Anthropology has much to offer in this endeavour as it concentrates on people in specific places and temporal contexts. It draws in the various worldviews, hopes, aspirations and knowledge that inspire people in their responses to mining. I write as an anthropologist who has undertaken research over the last three decades into many of the issues identified as crucial in debates about mining and sustainability. Ethnographic data illuminates theoretical formulations and theoretical analysis of data extends our knowledge and understanding of social phenomena. I offer these reflections evoked by this collection of articles, as instantiations of the value of utilising the concepts of place, movement and erasure.

\section{MOVING PEOPLE AND TRANSFORMING PLACES}

This article is protected by copyright. All rights reserved. 
In 1995 when a mining company was on the verge of beginning construction of a large gold mine, I was asked to attend a meeting of visiting company representatives and financiers and to explain the findings of an initial social impact assessment. The first question asked was: "Would it be possible to simply move all the people to another place? That would avoid so many of the potential problems that you've outlined." This solution fell into the category that I came to designate "Engineering Solutions", whereby a mining company proposes a relatively simple, physical or material change to obviate or mitigate a problem arising from their actions. One of the most common in Papua New Guinea, the site of my research, is to construct water tanks for villagers whose riverine water supply has been destroyed or compromised by mining activities. But unlike rivers, tanks are impermanent and less reliable water sources. They need maintenance and renewal to be a sustainable resource. While tanks and reticulated water through plastic pipes can be seen as evidence of "development", featured in glossy brochures that proclaim a company's commitment to the host community, they also epitomise unsustainable responses to environmental degradation of its natural resources. The application of unsustainable solutions to predictable problems often characterises strategies adopted by mining companies as they attempt to manage social and environmental impacts as quickly as possible.

In their contribution to this special issue, Bebbington and Humphreys Bebbington observe the ways that "place", "movement" and "development" are useful concepts for analysing and interpreting the effects of mining. The "place-making" activities are those of people - inhabitants, communities, mining company executives and employees, 
migrants and agents of governments. In Lihir, the site of a mining project in Papua New Guinea with which I am most familiar (see Bainton, 2010), the place-making activities of the mining company included the construction of a mine and its processing plant, the excavation of pits, the building of roads, a township, and accommodation for over 2000 employees. The mining company transformed areas of land that had previously belonged to specific lineage groups into a "Special Mining Lease". In that process the land attained new, measurable dimensions, linear boundaries that had previously simply been the sightlines between, for example, a rocky outcrop high on a mountain and a stand of sago palms by the shore. Such change is both material and conceptual, and laden with implications both for the previous landowners and the lessee. For those Papua New Guineans whose land becomes a commodity, subject to legal definitions that enable others to obtain primary rights in its use, it is also the site of their shift into the domain of capitalism (Patterson and Macintyre, 2011).

Place, place-making and development are multiplex concepts that can function as encompassing metaphors as well as precise analytical tools - and as several of the articles in this collection demonstrate, they interact. From an anthropological perspective, the variations in meaning reflect the ideas, ideologies and meanings that people attach to them. The voices and actions of the people who make or remake places, who move or stay, who embrace or resist mining projects are critical in reaching an understanding of mining and its consequences. 
Within the framework they propose, Bebbington and Humphreys Bebbington acknowledge that the different conceptions of sustainability in the context of mining determine or limit the ways that place-making occurs. The flow of ideas about what is to be sustained and the changing values accorded to place alter over time. People direct these flows and movements. They are the agents of change and often their ideas about sustainability and the values attached to places change dramatically over the course of a mining project.

As an anthropologist I have been consistently intrigued by the way that the commoditisation of land generates new values (Macintyre and Foale, 2007) and ideas of a good life. These ideas change, swiftly and dramatically, when a mining project arrives. For example, notions of economic stability and continuity based on productive land characterised Lihirian attitudes in the early years of mine construction. The company's commitment to rehabilitating the mine site by stockpiling topsoil was the subject of debate, suspicion and surveillance by landowners. They were adamant, and presumably convinced, that at closure the soil would be returned to its former place and the land could resume its function as the site of productive gardens. They set up a small covered structure on the road where trucks rolled past, laden with topsoil. They counted them and measured stockpiles of soft rock waste. At this stage, people clearly thought that at some future time their place would be remade and its capacity to grow gardens restored. This activity was abandoned after a few months. 
At about the same time, rumours about new areas of disturbance - sites that could yield compensation - circulated almost daily. A proposed road? Then people quickly moved in to make gardens along its presumed route in order to be able to claim compensation for loss of arable land and crops. The construction of the mine effectively encouraged people to engage in somewhat bizarre and temporary "place-making" of their own in anticipation of the changes that the mine would introduce. These hastily cleared gardens would never be harvested. This was not merely a way of gaining compensation; it was also a way of rethinking the value of land. Roads were perceived as more useful than the "instant gardens" that sprung up. People willingly sacrificed land for roads even as they tried to measure the loads of topsoil removed from the caldera where the new mine site was being established. Roads constituted signs of development.

\section{THE MEANINGS OF PLACES}

In some respects, the subjects of human migration and the movement of resources in the context of mining are so vast in scope, that adding consideration of sustainability seems overwhelming. Bebbington and Humphreys Bebbington bring a geographical sensibility to these topics, in ways that enable consistent intellectual scrutiny and comparison across regions. "Place" is at once a physical location and an abstraction dependent on the human imagination. People experience places differently, depending on their starting point. When I first visited Lihir, before mining construction began, I marvelled at Ladolam Bay and Luise Harbour as places of extraordinary natural beauty. Driving along a rough track, past the bubbling hot springs of Kapit, and then walking on the hot black 
sand with the rock outcrop of Ailaya looming behind me, I viewed this place aesthetically, almost like a tourist.

Meanwhile I was sharing the camp with geologists, engineers and drillers for whom it was a place of potentially valuable mineral deposits. They perceived it materially and in terms of the tasks that lay ahead. For them, the geothermal nature of the surrounding land presented intriguing and challenging technical problems. And for the people who had lived in villages around the shore, only those at the small village of Maron remained - they were soon to leave their place. Their mangrove trees would be bulldozed; Kapit's sulphurous streams and ponds with their bright yellow crystalline rocks would be reduced to a small, muddy, steaming pond on the edge of the road. The engineers envisaged then the technical challenge of releasing hot underground water and harnessing that energy to generate electricity. The use of geothermal energy in turn would be an environmental coup for the mining company, one that could reduce the need for fossil fuel while images of the geothermal power plant could adorn their brochures and proclaim their commitment to sustainability.

At that time, the remaining villagers in Maron had accepted that they would relocate and eagerly anticipated the new houses that they would acquire, courtesy of the mine. But they were deeply concerned about the burial ground of their ancestors being destroyed. The place was not merely the abode of the living, it was the resting place of the dead, and they were reluctant to abandon them to the depredations of mining. For them, the transformation of the area was an erasure of the material things that had sustained them 
for generations - their trees, homes, fishing grounds as well as the comfort that their ancestors were spiritually at rest in tended graves.

\section{MANAGING CHANGE AND MIGRATION}

The six questions posed by the editors in the Introduction (Bainton et al., 2018) have at their core the understanding of mining and migration as activities located in space and time. The various definitions and interpretations of place and place-making incorporate both change over time and the transformative processes that effect it. In thinking of that first visit to Lihir, I am struck by how the diverse understandings of place were generated simply by the prospect of mining. In the years that followed, all of these places became sites of construction and extraction. The caldera festooned with creeping vines turned into the deep, terraced pits; roads were constructed where coconut plantations had flourished; villages were razed and new ones built.

The speed of change is extraordinary, but made more so because it occasions an equally dramatic influx of people. The combination of a constantly changing landscape with an expanding and diverse population immediately threatens former ways of life and their sustainability. Mining projects are like magnets, especially in countries where opportunities for wage labour are scarce. Migration theory has remained consistently grounded in economics for over a century, and with good reason - the major factors that "push" or "pull" the movements of people remain economic. The contributors to this collection all note the economic determinants of migration into mining communities. Castillo and Brereton (2018) observe that there can also be an out-flow as people use 
benefits to move to towns "precisely because they present greater economic opportunities and offer better services". Their strategies draw on social capital and familial networks to do so.

Jackson (2018) notes that the geographical location of mines, often in remote "undeveloped" areas, means that they are rarely conducive to flourishing and sustainable development projects, for precisely the reasons that they had remained undeveloped before. They flourish while the mine is operating and people depart when it closes. Castillo and Brereton suggest that migration in and out of a mining area in Peru is determined mainly by the opportunities for employment or economic benefit, but that movements are also to be understood in terms of kinship and relational networks. Certainly, the motivations and strategies vary, but in Papua New Guinea, the initial influx of migrants is usually made up of people who have moved away from their "undeveloped" location for employment and return as the possibility arises in their own place. Mining companies encourage this by placing advertisements and arranging meetings with highly qualified "expatriate" people living in towns. It is viewed as a way of avoiding some of the conflicts associated with employing people who are considered strangers or interlopers. While this might be interpreted as a kinship connection strategy, it also reflects the fact that it enhances the returnees' standard of living because they have access to land at home.

But as Bainton and Banks (2018) point out, movement out is more problematic in Papua New Guinea where access to land is legally constrained. Porgera, a formerly remote, 
sparsely populated region, has experienced more than a tenfold increase in population. The existing system of land tenure provided ways of incorporating migrants into a subsistence economy, thus enabling migrants to exploit established kinship and alliance networks with the advent of the mine. In the early years of the mine in Lihir, numerous migrants were "adopted" into clans in order to gain access to employment as locals. They were usually required to pay a portion of their wages to their adopter.

A few of the wealthier landowners from Lihir and Porgera have purchased properties in the capital city, Port Moresby, and in Cairns or Brisbane in Australia. Some are escaping the demands of kin who want a share in the compensation payments; some are too scared to remain in Porgera because they have defrauded kin of their share. For a minority, the "outflow" is simply an investment property that will ensure their future economic and personal security. Papua New Guinea is a rentier state in which "the popular perception of 'development' as the collection of a resource rent reflects the real historical tendency for an ever-increasing proportion of the national income to be obtained in this form" (Filer, 1997: 172). "Development" and "sustainability" can then be financial strategies that serve individualised interests. So, while outmigration might redistribute wealth from periphery to centre in Peru, where the flow of money can move back and forth between kin, it does not appear to do so in Papua New Guinea. The individual accumulation of wealth through rents can hardly be considered a stable or secure form of economic development, either at the national or individual level. As recent analysis of the ExxonMobil Liquefied Natural Gas project demonstrates, the wealth flowing to the company and its shareholders has been abundant (Main and 
Fletcher, 2018). Landowners and citizens of Papua New Guinea more generally have yet to receive any of the promised benefits.

The influx of migrants seeking employment or business opportunities is rarely unproblematic for the original inhabitants and often causes conflict. On islands such as Bougainville, Misima and Lihir, the ecological and environmental damage caused by mining are exacerbated as the population grows. More land is lost to housing newcomers; arable land diminishes in area and fertility. Modes of subsistence agriculture are rendered unsustainable. Opportunities for tandem development schemes founder in the struggle for jobs and the hopes for a better life. The articles by Jackson and Bainton and Banks illustrate the problematic status of arguments for mining as a catalyst for new modes of sustainable development. Very often, tandem (often agricultural) projects are encouraged or funded by mining companies or government agencies, only to collapse when mining ceases. The reasons are clear - people perceive these projects as inimical to their ideas of "development". They do not want to be farmers, they want to continue to participate in an industrial economy or engage in commerce. In Papua New Guinea, where business development is invariably a strategy aimed at diversifying economic development during the life of the mine, these usually service the mining company and are not sustainable beyond that time (Bainton and Macintyre, 2013).

\section{WHAT IS SUSTAINED?}

In 2015 the United Nations proclaimed seventeen Sustainable Development Goals that were to be applied globally. These are dependant upon capitalist assumptions of 
economic growth as an indicator of social development and improvement in living standards. There is hierarchy of goals in which "Industrial development" (Goals 8 and 9), has higher priority than "Life on land" (Goal 15), which requires government protection of terrestrial ecosystems, forests and mountain environments as well as the reversal of land degradation. The tension between mining as a successful form of industrial development and the sustainability of ecosystems, forests and mountains is at the heart of the problems discussed in this collection. There is no debate about mining as a quintessentially unsustainable industry. It cannot avoid degradation of the land. It is usually also economically unsustainable. But for the past three decades mining companies have been forced to take some responsibility for "sustainable development" in mineaffected regions. Mine closure plans usually incorporate projects that will yield some economic benefits or opportunities to their hosts.

Some of these plans can only be interpreted as cynical public relations exercises that attempt to whitewash (or greenwash) the environmental damage that has been wreaked. For instance, in Misima, where the abandoned pit is now a highly acidic lake, the mining company left the means for hydro-electricity to be generated - an "engineering solution" that is unsustainable without fuel and maintenance. Small "income generating" projects founder in the absence of accessible markets.

The making of mine sites and the building of infrastructure essential for the operation of a mine ensure that the land that was there before is transformed. Even in places where rehabilitation succeeds closure, the place is never the same. I recall vividly a visit to an 
Australian mine site where the company was reforesting some sections of the lease area and planting indigenous grasses, bushes and wildflowers in another. As the area had previously been a cattle run, this enterprise went beyond restoration - that would have merely required planting some straggly mulga trees and allowing grass to grow. The reforested land was pitifully small and the indigenous plants area even smaller. The tailings pond would be covered with cement; yet another "engineering solution". It was a public relations exercise rather than a commitment to ecological restoration and environmental sustainability.

\section{MORAL RESPONSIBILITY}

In the 1980s and 1990s mining companies did acknowledge the need to "reduce the footprint" of mining, socially and environmentally. Mine closure plans increasingly incorporated responses to the economic problems they had been instrumental in creating and the damage inflicted on the environment. The social impacts of mining were recognised to some degree, but in most instances were only treated seriously when they threatened profitability. Social impacts and ensuing conflicts were construed as "social risk" and, like other risks in their business, were assumed to be calculable and to have a monetary value. Avoiding and managing social risk became the province of the Community Relations departments.

Community Relations activities and departments were acceptable also as a "Public Relations" component of business practice and as means of gaining access and assent to mining. The rhetoric of "social responsibility" was a response to the rising tide of 
criticism from Non-Government Organisations and other international agencies in the wake of dramatic social conflicts such as the civil war in Bougainville that emerged from local mining conflicts, and environmental disasters such as the Ok Tedi mine. For mining companies it became a vital instrument in attracting investment and reassuring shareholders.

The concluding article in this collection by Kemp and Owen (2018) raises the question of moral responsibility in finding solutions to the problems generated by mining, migration and those policies and practices that are antithetical to sustainability. They show how ideals of long-term social benefit, of economic and environmental sustainability briefly embraced by the mining industry in the Mining, Minerals and Sustainable Development project of the 1990s (IIED, 2002) have been cynically abandoned in the interest of profit. It raises doubts and questions about the usefulness of informed critique and detailed analysis of the social and environmental impacts of mining. If mining companies are discounting the value of such research and avoiding the implementation of policies to manage the damage they inflict on people and places, the outlook is grim. If the governments of countries where resource extraction dominates the economy fail to regulate the mining industry so that disasters are avoided, then they are morally culpable too.

\section{REFERENCES}

Bainton, N., A (2010). The Libir Destiny: Cultural Responses to Mining in Melanesia. Canberra: ANU Press. 
Bainton, N.A. and Banks, G. (2018). Land and access: A framework for analysing mining, migration and development in Melanesia. Sustainable Development. This issue.

Bainton, N.A., Owen, J.R., and Kemp, D. (2018). Mining, mobility and sustainable development: An introduction. Sustainable Development. This issue.

Bainton, N.A. and Macintyre, M. (2013). 'My Land, My Work': Business development and large-scale mining in Melanesia. In McCormack, F. and Barclay, K.. (Eds), Engaging with Capitalism: Cases from Oceania (pp 139-165). United Kingdom: Emerald Books. Economic Anthropology, Vol. 33.

Bebbington, A. and Humphreys Bebbington, D. (2018). Mining, movements and sustainable development: Concepts for a framework. Sustainable Development. This issue.

Castillo, G. and Brereton, D. (2018). Large-scale mining, spatial mobility, place-making and development in the Peruvian Andes. Sustainable Development. This issue.

Filer, C. (1997). Compensation, Rent and Power in Papua New Guinea. In Toft, S. (Ed), Compensation for Resource Development in Papua New Guinea. Canberra: PNG Law Reform Commission and Australian National University.

International Institute for Environment and Development (IIED). (2002). Breaking New Ground: Mining, Minerals, and Sustainable Development. London: Earthscan.

Jackson, R.T. (2018). Migration to two mines in Laos. Sustainable Development. This issue. 
Kemp D. and Owen, J.R. (2018). The industrial ethic, corporate refusal and the demise of the social function in mining. Sustainable Development. This issue.

Macintyre, M. and. Foale, S. (2007). Land and marine tenure, ownership and new forms of entitlement on Lihir: changing notions of property in the context of a goldmining project. Human Organization 66(1): 49-59.

Macintyre, M. and Patterson, M. (2011). Capitalism, cosmology and globalisation in the Pacific. In Patterson, M. and Macintyre, M. (Eds), Managing Modernity in the Western Pacific (pp 1-29). St Lucia: University of Queensland Press.

Main, M. and Fletcher, L. (2018). On Shaky Ground: PNG LNG and the consequences of development failure. Sydney: Jubilee Australia. Retrieved from http://www.jubileeaustralia.org/latest-news/second-report-exploring-the-png-lngproject 


\section{University Library}

\section{- M M N E R VA A gateway to Melbourne's research publications}

Minerva Access is the Institutional Repository of The University of Melbourne

Author/s:

Macintyre, M

Title:

AFTERWORD Places, migration and sustainability: anthropological reflections on mining and movement

\section{Date:}

2018-09-01

\section{Citation:}

Macintyre, M. (2018). AFTERWORD Places, migration and sustainability: anthropological reflections on mining and movement. SUSTAINABLE DEVELOPMENT, 26 (5), pp.501-505. https://doi.org/10.1002/sd.1895.

Persistent Link:

http://hdl.handle.net/11343/284719 